UNIVERSITA' DEGLI STUDI DI BOLOGNA DIPARTIMENTO DI SCIENZE ECONOMICHE

\title{
The Euro-dividend: public debt and interest rates in the Monetary Union
}

Luigi Marattin

Simone Salotti 


\title{
The Euro-dividend: public debt and interest rates in the Monetary Union
}

\author{
Luigi Marattin $^{ \pm}$ \\ University of Bologna
}

\author{
Simone Salotti ${ }^{\circ}$ \\ University of Florence
}

\begin{abstract}
The ongoing massive fiscal policy stimulus triggered increasing concerns on the potential impact on interest rate levels, as economic theory predicts. Particularly, the deterioration of some EMU countries' fiscal positions has been putting at risk Eurozone' financial stability. In this paper, we estimate a Panel VAR (PVAR) model on the EMU area employing annual data from 1970 to 2008 in order to assess the qualitative and quantitative impact of public debt on interest rates Our results show that prior to the introduction of the Euro an increase in public debt led to positive and significant effect on long-term nominal interest rates, with a stronger effect for high-debt countries. After the introduction of the single currency, the effect vanishes (in line with Bernoth 2004). We interpret this result as a confirmation of the crucial role of the monetary union in weakening the automatic risk-premium-based channel between debt shocks and returns on government bond.
\end{abstract}

JEL classification: E62, G12

Keywords: Panel VAR, Fiscal policy, government bond's yields.

\footnotetext{
${ }^{ \pm}$Department of Economics - Strada Maggiore 45 - 40125 - Bologna (Italy). Email: luigi.marattin@unibo.it Department of Mathematics for Decisions - Via Lombroso 6/17 - 50134 - Florence (Italy). Email: simone.salotti@unifi.it
} 


\section{Introduction}

The implementation of expansionary fiscal policies in response to the 2008-2009 recession required massive increases in public debt issuances all over the world. Table 1 shows the gross issues in the EMU area from 2004 to the forecasting for 2010: the average of 2009-2010 is sixty per cent higher than the corresponding value for 2004-2008. ${ }^{1}$ Particularly, large EMU economies will experience substantial increase in 2010, as reported in Table $2 .^{2}$

Such an unprecedented deterioration of public finance conditions is raising considerable concerns regarding the possible negative effect on interest rates. Particularly, there is a widespread concern in the European Monetary Union (EMU), where the conduct of the common monetary policy could be damaged by a generalized increase in yields on the capital market driven by the deterioration of national fiscal conditions. In early 2010, concerns about fiscal solvency of some EMU countries (the so-called "PIGS": Portugal, Ireland, Greece and Spain), with the widening of within-EMU government bonds' interest rates spread and talks of possible bail outs, is jeopardizing Eurozone’s financial stability. ${ }^{3}$

However, is the negative relationship between public debt and interest rate really an unambiguous feature? Economic theory offers a rather clear-cut answer to the question. In the short run the resulting increase in aggregate demand under price stickiness boosts inflation and - through monetary policy - the nominal short term interest rate, whose movements are usually transmitted along the yield curve. ${ }^{4}$ In the long run the negative effect is ensured by the standard crowding-out effect (Ball and Mankiw 1995, Elmendorf and Mankiw 1999) which decreases aggregate capital stock and, by diminishing returns, increases the real rate of interest. As Faini (2006) shows, this effect can be softened - or possibly reversed - if the model includes a parallel compensating private savings flow. The above mechanism can in fact be wedged by consumers' pure Ricardian behavior or by the degree of openness of the economy (i.e. the decrease in public saving is offset,

\footnotetext{
${ }^{1}$ To set a comparison, data for corporate bonds' new issues are 150 billions of euro in 2007, 136 in 2008,299 in 2009 and 215 in 2010.

${ }^{2}$ Italy, France, Spain, Germany, Belgium and Finland represent approximately 60\% of EU-27 total GDP.

${ }^{3}$ The spread between Greece and Germany's government bond's yields is currently (as of February 2010) beyond 300 basis points.

${ }^{4}$ To the extent that the increase in public debt triggers inflation expectations, long-run interest rate can be affected immediately through that channel.
} 
respectively, by increase in private savings or by international capital flows ${ }^{5}$ ), or by perfect substitutability between private and public spending (Bouakez and Rebei 2007, Linneman 2004).

In this paper, we implement a Panel VAR (PVAR) model on 11 EMU countries using annual data 19702008. Our results show the existence of a positive and significant relationship between public debt and longterm nominal interest rate before the introduction of the Euro and in particular for high-debt economies, defined as those with a debt/GDP ratio above the median. This result would therefore confirm the existence of the so-called "dividend of the Euro”, namely the macroeconomic benefits arising from EMU membership through the credibility gain and the disappearance of the devaluation option. However, if not disciplined by any efficient coordination mechanism on the fiscal side, the unconstrained exploitation of the Euro-dividend is doomed to eventually cause troubles. Which is probably what we are experiencing at the moment.

The rest of the paper is organized as follows. Next section contains a short review of the previous empirical literature on the effects of debt on interest rates. Section 3 presents our dataset, the empirical model and our identification strategy. Section 4 shows our results, accompanied by a variety of robustness checks. Section 5 concludes and discusses policy implications.

\section{A short review of the literature}

A quite large empirical literature has been developed to verify the sign and - most importantly - the magnitude of the debt effects on interest rates. These contributions differ according to the econometric methodology employed: in particular, we can broadly distinguish between a non-VAR and a VAR literature. ${ }^{6}$ The non-VAR literature includes a relatively higher number of contributions. Laubach (2009) uses a dynamic OLS framework in order to investigates the quantitative effects of government debt and deficits on long-term interest rate for US economy (1976-2006); to overcome the endogeneity problem he uses variables' projections instead of current values. He founds that a 1 per cent increase in the projected deficit/GDP ratio raises the 5-year-ahead 10-year forward rate by 20 to 29 basis points, whereas the same increase in debt/GDP ratio raises the forward rate by 3 to 4 basis points. Ardagna et al. (2007) use a dynamic

\footnotetext{
${ }^{5}$ Fedstein and Horioka (1980).

${ }^{6}$ The importance of the underlying methodology is confirmed by Miller and Russek (1996), who address the issue using three different econometric approaches (the London School, the Bayesian and the VAR methods). They find that while the first two provide evidence on the effects of federal budget deficit on US long-term interest rates, the VAR analysis does not confirm such a result.
} 
GLS model to investigate a panel of 16 OECD countries (1960-2002) and find significant effects of fiscal imbalances on long-term interest rate. In their best model's specification, a 1 per cent increase in primary deficit/GDP ratio is associated with a 10 basis points increase in nominal interest rate on 10 years government bond; the cumulative response after ten years is equal to 150 basis points. They also investigate the impact of debt, finding a non-linear effect: the response of long term interest rate is positive and statistically significant only when the existing stock of public debt is above a given threshold. There is also some evidence on the impact of country-specific fiscal imbalances on a wider level. Along the same line, Faini (2006) uses a three-stages least squares focusing on nine EMU countries (over the period 1979-2002) and finds that an expansionary fiscal policy in one EMU member has effects both on its spread and on the overall level of interest rate for the currency union (with the latter being stronger than the former). Although less robust, there is also evidence of more significant spillover effects for high debt countries. Bernoth et al. (2004) use a panel data analysis (1991-2002) on 13 EMU nations to investigate the effects of fiscal imbalances (and EMU membership) on spread to German bond. They find that an increase of 1 per cent in the deficit/GDP differential with Germany increases spread by 3.39 basis points although in a non-linear fashion. A 25 per cent differential in debt/GDP ratios corresponds to a 30 basis points, whereas 50 per cent corresponds to 47.5 basis points. However, they find that EMU membership implicated a reduction in spreads.

The importance of default risk in explaining yield differentials in the government bond markets within the EMU area is also confirmed by Codogno et al. (2003), who estimate a dynamic model with the particular aim of distinguishing between credit risk (measured by international risk factor and domestic fiscal variables) and liquidity components. They find that changes in international risk factors - as measured by US corporate bonds spread relative to US Treasury yields - affect the perceived default risk of government bonds in the EMU area; for selected countries (Italy, Austria and Spain) the impact of international risk on yield differentials is explained by their debt/GDP ratio relative to Germany.

VAR evidence on fiscal policy's effects on government bonds yields is much more scarce and controversial; furthermore, the few studies available are mainly focused on US economy. Engen and Hubbard (2004) find that an increase in projected US federal debt increases (expected or current) 5-year Treasury bonds interest rates by 1.5 or 2.5 basis points. Their VAR-based results are basically confirmed by conventional reduced- 
form specifications. On the other hand, Evans and Marshall (2007) use monthly data on US economy from 1959 to 2000 and find virtually no effects of fiscal shock on interest rates. Over the same time span and frequency, Ang and Piazzesi (2003) look at the role of macroeconomic factors in explaining government bond yields. By using a traditional VAR analysis where no-arbitrage conditions are imposed as identification restrictions, they find that macroeconomic factors explain up to 85 per cent of the forecast variance for long forecast horizons at short and medium maturities of the yield curve; the proportion of the variance attributable to macro factors decreases along the yield curve.

One of the few VAR analysis on EU economies is provided by Favero et al. (1997). However, they adopt a substantially different focus with respect to our present contribution. In fact, they study the high-frequency fluctuations of three high-yielders - Italy, Spain and Sweden - over a limited time span (January 1993September 1995), in order to assess the functioning of the Exchange Rate Mechanism (ERM) in those particularly turbulent years. They find the existence of a common long-run stochastic trend between Italian and Spanish interest rate spreads, driven by international factors and independent of country-specific shocks, which however preserve their role in the short-run dynamics.

To the best of our knowledge, no previous VAR- analysis investigates explicitly the debt-interest rate relationship in the European economic space. Our contribution aims at filling this gap in the literature, with an approach to be presented in the following section.

\section{Data and the empirical model}

Our approach is based on a PVAR with annual data. The main advantage of the PVAR technique consists in the combination of the traditional VAR approach (flexible and capable of dealing with the endogeneity problem) with panel data analysis (which allows for unobserved individual heterogeneity). While the advantage of using panels consists in an increase in the number of observations, the disadvantage is the need to impose certain homogeneity restrictions. However, by focusing on EMU countries only, we limit the potential heterogeneity, as the EMU economies share many similarities and are part of a monetary union. The structural form of our PVAR model is given by:

$$
A_{0} Z_{i t}=A(L) Z_{i t-1}+e_{i t}
$$


where $Z_{i t}$ is an $(m x 1)$ vector of endogenous variables; $A_{0}$ is an $(m x n)$ matrix with 1 's on the diagonal and contains the parameters that capture the contemporaneous relations among the variables; $A(L)$ is a matrix polynomial in the lag operator $L$; finally, $e_{i t}$ is the structural disturbance vector. Pre-multiplying (1) by $A_{0}^{-1}$, we obtain the reduced form that we can actually estimate:

$$
Z_{i t}=B(L) Z_{i t-1}+u_{i t}
$$

where $B(L)=A_{0}^{-1} A(L)$ and $u_{i t}=A_{0}^{-1} e_{i t}$ is the reduced form residual vector.

In the baseline specification, the vector $\mathrm{Z}$ is as follows: $Z_{i t}=\left[d e b t_{i t}, G D P_{i t}, l t i r_{i t}\right]$, where debt $_{i t}$ is the stock of real government debt, $G D P_{i t}$ is real aggregate activity, ltir $_{\text {it }}$ is the 10 -years nominal interest rate on government bonds. All variables are first differences, real, and expressed in logs. We tested the presence of a cointegrating relationship among the variables of the PVAR, and we found none. Unit root tests (available upon request) show that the series are all integrated of order one in our sample, thus we proceeded with the estimation of the PVAR in first differences (that is, with stationary variables).

Our identification scheme is based on a lower triangular Cholesky decomposition with the above indicated ordering. Hence, a variable coming earlier in the ordering affects the next ones both contemporaneously and with a lag, while a variable coming later has merely lagged effects on the preceding ones. In our model, such a identification strategy amounts to assuming that long-term nominal interest rates affect aggregate activity and the stock of public debt only with a one-period lag. These might be viewed as pretty harmless assumption, due to - respectively - lags in implementation of investment decisions and the standard formulation of government intertemporal budget constraint in macro models. Moreover, we do not allow a contemporaneous effect of GDP level on the stock of government liabilities, which again is consistent with the formulation of fiscal policy rules targeting - whenever sensitive to the business cycle - last period output gap. Instead, we allow contemporaneous effect of aggregate activity on interest rate (through monetary policy rule and the transmission along the yield curve), and of public debt on both GDP and interest rate, which is the focus of our investigation.

Our sample consists of 11 EMU countries (Austria, Belgium, Finland, France, Ireland, Italy, Germany, 
Greece, the Netherlands, Portugal and Spain) over the period 1970-2008. ${ }^{7}$ Our data are mainly from the OECD Economic Outlook no. 85, although we integrated this source with the Main Economic Indicators (published by the European Commission) in order to get a balanced panel dataset.

The use of a PVAR approach requires the underlying structure to be the same for each cross-sectional unit. This is likely to be violated in practice, even if focusing on the EMU ensures a certain degree of similarity among the countries of the sample. Nevertheless, we allow for individual heterogeneity by introducing fixed effects. Since they are correlated with the regressors due to the lags of the variables, the mean-differencing procedure commonly used to eliminate fixed effects will create biased coefficients. To overcome this problem, we use forward-mean differencing (Helmert procedure, see Arellano and Bover, 1995). This procedure preserves the orthogonality between transformed variables and lagged regressors, thus we use lagged regressors as instruments and estimate the coefficients by system GMM (Love and Zicchino, 2006). ${ }^{8}$ Next section illustrates the results of our analysis. We focus on the impulse-response functions, which describe the reaction of one variable in the system to the innovations of another variable while holding all other shocks at zero (that is, we use orthogonalized shocks).

\section{Estimation results}

This section contains our main results of the empirical model outlined in section 2. In subsection 4.1 we estimate our model on the whole panel (11 EMU countries on the 1970-2008 time span) and comment the results. In the following subsection (4.2) we investigate two further dimensions of the analysis. Finally, subsection 4.3 deals with robustness tests.

\subsection{The whole sample}

Figure 1 displays the impulse response functions to a one per cent increase in the real stock of public debt (details are contained in Table 4).

Figure 1 about here

\footnotetext{
${ }^{7}$ The panel is balanced, apart from very few missing values (Greece 1970-1972 \& 1989-1991, interest rate; Ireland 1970, interest rate; Portugal 1970-1972, debt). We excluded Luxembourg due to limited availability of fiscal variables. Note that Slovenia, Cyprus, Malta and Slovakia also are part of the EMU, but we excluded these countries from the sample since they only became member between 2007 and 2009.

${ }^{8}$ To perform the analysis we used the Stata pvar routine written by Inessa Love (see Love and Zicchino, 2006).
} 
The long term interest rate reacts positively to debt shocks, with a peak on the second year after the shock; however, the impulse response is not statistically significant at conventional levels. As for the impact on GDP, there is a small negative effect on impact (-0.07\% of GDP), but it dies out after one year. Such a result would therefore point towards the non-existence of a well defined relationship between fiscal shocks and nominal interest rates. However, there are two dimensions that are worth exploring in order to deepen the analysis: the structural break represented by the establishment of the EMU, and the heterogeneity in public debt's levels.

Particularly, the introduction of a common monetary policy with a strong and explicit mandate on inflation, coupled with the enforcement of fiscal policy constraints (the Maastricht criteria and the Stability and Growth Pact) might have played a crucial role in breaking the link between fiscal shocks and interest rates on the capital market, due in particular to credibility gains in the monetary policy conduct. In addition to that, the potential non-linearity in the panel related to different levels of public debt among EMU countries are worth an analysis. Table 3 reports the average debt/GDP levels of the 11 countries in our sample, both in the pre-EMU and post-EMU periods. According to that information, we label Belgium, Greece, Ireland, Italy and Netherlands as "high-debt countries", whereas the remaining ones will be referred to as "low-debt countries”.

Having established these two further dimension of analysis, we proceed by estimating our PVAR first on the two different time spans (pre-EMU and post-EMU), and then on the two different sub-samples ("high-debt countries” and “low-debt countries”).

\subsection{EMU and average fiscal position matter.}

Figure 2 shows the results of the PVAR model on the 1970-1996. Note that we used the year 1997 as starting date for EMU because admissions were agreed on May 3rd 1997, and national exchange rates were irrevocably fixed from that day on. However - as also mentioned in the robustness analysis in section 5 using 1998 does not change our results qualitatively, and only very little on the quantitative side.

The first column reports the impulse response function for the whole sample, while the remaining two respectively - for high-debt and low-debt countries (Tables 5-7 contains the detailed results). 


\section{Figure 2 about here}

We can now observe some features that were hidden in the previous subsection's analysis. First of all, the first column of figure 2 shows that, prior to the introduction of the Euro, in the whole countries-sample a 1 per cent increase in government debt lead to a positive and significant rise in interest rates (20 basis points on impact, 17 in the first year).

Secondly, this effect is much stronger for economies featured by a relatively higher level of government debt than it is for disciplined countries. For the former group, (second column) the effect of the debt-shock is equal to a rather substantial 43 basis points increase on impact (and additional 42 in the first year); for the latter (third column), the impact is much smaller (15 basis point on impact) and not statistically significant at standard levels. Thus, the same kind of non-linearity found by Ardagna (2007) for OECD countries is confirmed here at the EMU level.

In line with similar result obtained by Bernoth (2004) and discussed in section 2, we found that the creation of the EMU stands as a structural break in the relationship between government debt and interest rates. Before its introduction, long-term interest rates were sensitive to non-systematic increase in public debt, pointing out that the textbook channels were fully at work. Our model indicates that after the establishment of the monetary union this effect vanishes. However, results so far tell us nothing about the role of heterogeneity in debt levels per se. In other words, accounting for this kind of heterogeneity could be meaningful regardless of the introduction of the euro. To check that, we run our model on the whole time span (1970-2008) for both high-debt and low debt countries sub-samples. Figure 3 shows the corresponding impulse response functions (details in Tables 8 and 9):

Figure 3 about here

First and second columns show, respectively, results for the high-debt and low-debt countries sub-samples. They confirm the fact that the long term interest rate reacts in a more substantial way to debt shocks in high debt countries (the impact reaches a peak of 20 basis points after one year, while the peak for the low debt 
countries is reached after four years and amounts to 10 points only). However, none of the interest rates responses are significant at conventional levels. Thus, a difference in the pre-existing stocks of government liabilities (which can be seen as an autonomous risk indicator) does not account per se for the significance of the relationship under investigation.

We can therefore conclude that between the introduction of the EMU and the asymmetric position of high/low debt economies, the critical issue is the former; no substantial role for that differentiation, in fact, is found over the 1970-2008 period. Nonetheless, within the pre-EMU regime we can still notice a dual impact: a 1 per cent increase in government liabilities in high-debt countries caused a rise in interest rates almost three times higher than in more disciplined economies.

The interpretation that we offer of our results is the following. In the short-term - as impulse response functions in a VAR analysis necessarily are - shocks on debt display effects on government bond yields essentially through the risk premium perception. To the extent that risk is an increasing function of the existing stock of public liabilities, this explains our results on the non-linearity effects. However, the crucial feature seems to have been the establishment of the monetary union. The disappearance of exchange rate risk, the strong anti-inflation mandate to the European Central Bank, and the fiscal discipline imposed by the Stability and Growth Pact seem to have affected the causality chain that goes from debt shocks - through risk perception - to bonds 'yields, thereby providing a sort of common "umbrella" to isolate returns on government bond from associated risk perception. Each of the three above-mentioned factors, in fact, played a role in the transmission mechanism. The possibility of competitive devaluations of national currencies (possibly triggered by excessive debt accumulation) had always been crucial in accounting for spreads in the short term (see Favero et al. 1997); lack of credibility and discretionary monetary policies (only partially disciplined by the exchange rate mechanism) by some national central banks did not contrast the transmission of debt shocks to interest rate term structure. Finally, the lack of explicit constraints for fiscal discipline was the primary engine to set off the transmission. Obviously those three factors - and the related gains stemming from their disappearance - were not equally spread among perspective EMU members (no doubt southern Europe countries gained from EMU umbrella more than continental economies); nonetheless, our analysis looks at the overall dimension of the monetary union, regardless of national specificities before and after admission. 


\subsection{Robustness tests}

We checked the validity of the results reported in the previous subsections along two distinct lines of robustness test.

First we estimate our model as in equation (1) with different specifications. We used the long-term real interest rate (instead of the nominal), changed the Cholesky order and varied the end of the pre-EMU period from 1996 to 1997 (as reported earlier in the text). None of the above alternative changes produces any significant modifications in our benchmark results.

Secondly, we wanted to control for the possible relative role of one country in the sample in determining our results. Thus we re-estimated our PVAR excluding from the sample one country at a time, in order to verify whether our results depend critically on one national economy. Figure 4 here below reports the collection of impulse response functions generated by these attempts, both on the whole time span (left column) and in the pre-EMU period (right column).

Figure 4 about here

It is clear that all functions are centered on those reported in previous sections, so we can reasonably rule out the possibility that our results are driven by one particular row in our panel.

\section{Conclusions and policy implications}

The timing of the crisis is sadly straightforward, and seems to overlap pretty well with the yearly calendar. The burst of the financial crisis (2007), followed by the transmission to the real side of the economy (2008), and then the impressive monetary and fiscal stimulus measures to contrast the heavy downturn (2009). The year 2010 will probably be dominated by the macroeconomic consequences of the recovery plans, particularly on public finances (heavily stressed all over the world) and particularly in the EMU, which is facing its first important test. Much of the attention has focused on the effects of fiscal imbalances on the debt service; empirical literature seems to have privileged non-VAR analysis on US (or at best OECD) economy. In this paper, we focused on EMU area with a Panel VAR methodology which allowed us to enjoy 
a substantial number of observations (39 annual observations for 11 countries) without being damaged too much by the implied homogeneity restrictions, given the degree of integration achieved by EMU economies at least on the macroeconomic side.

Our results show that a positive and significant relationship between public debt and interest rate emerges only before the introduction of the single currency with a substantial asymmetry between high and low debt countries (defined as those with a debt/GDP ratio higher/lower than the median); while a one per cent increase in the stock of government liabilities causes a 43 basis point increase on 10-year government bond's yields for high-debt economies, the impact is much smaller (and less significant) for more disciplined countries. Our results also show that as the non-linearity in the effects is significant only in the pre-EMU period, the crucial feature in breaking the transmission of credit risk to interest rate seems to have been the establishment of the monetary union.

This result offers at least two alternative interpretations: if, on one hand, it seems to confirm the crucial role of the single currency in providing a "macroeconomic shield" (or Euro-dividend) for less disciplined economies, on the other it suggest a possible moral hazard problem. The existence of such a safety net, in fact, might disincentive the pursue of balanced national fiscal positions; until the Stability and Growth Pact was fully effective, the moral hazard had somehow been disciplined, although maybe imperfectly. When the burst of the crisis made the SGP-constraint less binding, the problem emerged in all its severity, starting from peripheral EMU countries such as Greece, Portugal and Spain. On the top of that, the increasing use of Credit Default Swap contracts (CDS) as risk management tool on financial assets - and specifically government bonds - is creating a new transmission channel of country risk. High-frequency data such as those available on CDS can hardly be inserted in a traditional VAR analysis like the one contained in this paper; nevertheless, incorporating the information conveyed by the price of those assets into empirical macroeconomic analysis is a promising suggestion for future work in this area. 


\section{References}

Ang, Andrew and Monika Piazzesi (2003). “A No-Arbitrage Vector Autoregression of Term Structure

Dynamics with Macroeconomic and Latent Variables.” Journal of Monetary Economics, 50, 745-787.

Ardagna, Silvia, Francesco Caselli and Timothy Lane (2007). “Fiscal Discipline and the Cost of Public Debt Service: Some Estimates for OECD Countries.” The B.E.Journal of Macroeconomics. Vol. 7(1), Article 28. Arellano, Manuel and Stephen Bond (1995). “Another look at the instrumental-variable estimation of error components models.” Journal of Econometrics. Vol. 68, 29-52.

Ball, Lawrence and Gregory Mankiw (1995). “What Do Budget Deficits Do?” Budget Deficits and Debt: Issues and Options. Kansas City: Federal Reserve Bank of Kansas City, 95-119

Bernoth, Kerstin, Jurgen Von Hagen and Ludger Schuknecht (2004). “Sovereign Risk Premia in the European Government Bond Market.” ECB Working paper 369.

Bouakez, Hafedh and Nooman Rebei (2007). "Why Does Private Consumption Rise After a Government Spending Shock?” Canadian Journal of Economics, Vol.40(3), 954-979.

Codogno, Lorenzo, Carlo Favero, Alessandro Missale, Richard Portes and Marcel Thum (2003). "Yields Spreads on EMU Government Bonds.” Economic Policy. Vol. 18(37), 503-532.

Elmendorf, Douglas and Gregory Mankiw (1999). “Government Debt.” Handbook of Macroeconomics. J. Taylor and M. Woodford (eds), Amsterdam, Elsevier Science, Chapter 25.

Engen, Eric and Glenn Hubbard (2004). "Federal Government Debts and Interest Rates.” NBER Working paper No.10681.

Evans, Charles and David Marshall (2007). "Economic Determinants of the Nominal Treasury Yields Curve.” Journal of Monetary Economics. Vol 54(7), 1986-2003.

Faini, Riccardo (2006). “Fiscal Policy and Interest Rates in Europe.” Economic Policy. Vol. 21(47), 443-489. Favero, Carlo, Francesco Giavazzi and Luigi Spaventa (1997). “High Yields: The Spread on German Interest Rates.” The Economic Journal. Vol.107(443), 956-985.

Feldstein, Martin and Charles Horioka (1980). "Domestic Saving and International Capital Flows.” The Economic Journal. Vol. 90(358), 314-329.

Laubach, Thomas (2009). “New Evidence on the Interest Rate Effects of Budget Deficits and Debt.” Journal of the European Economic Association. Vol. 7(4), 858-885. 
Linnemann, Ludger and Andreas Schabert (2004). “Can Fiscal Spending Stimulate Private Consumption?” Economic Letters. Vol. 82(2), 173-179.

Love, Inessa and Lea Zicchino (2006). "Financial Development and Dynamic Investment Behavior: Evidence from Panel VAR.” Quarterly Review of Economics and Finance. Vol. 46(2), 190-210.

Miller, Stephen and Frank Russek (1996). “Do Federal Deficits Affect Interest Rate? Evidence from Three Econometric Methods.” Journal of Macroeconomics. Vol. 18(3), 403-428. 


\section{Tables}

Table 1: debt issue 2004-2010 in the EMU area (billions of euro)

\begin{tabular}{cccccccc}
\hline Year & $\mathbf{2 0 0 4}$ & $\mathbf{2 0 0 5}$ & $\mathbf{2 0 0 6}$ & $\mathbf{2 0 0 7}$ & $\mathbf{2 0 0 8}$ & $\mathbf{2 0 0 9}$ & $\mathbf{2 0 1 0}$ \\
\hline Debt issue & 591 & 591 & 590 & 577 & 670 & 932 & 1005 \\
\hline Source: Calyon; Deutsche Bank
\end{tabular}

Table 2: 2009-2010 variation in some EMU economies (billions of euro)

\begin{tabular}{cccc}
\hline Country & $\mathbf{2 0 0 9}$ & $\mathbf{2 0 1 0}$ & growth \\
\hline Germany & 158 & 177 & $+12 \%$ \\
France & 178 & 210 & $+18 \%$ \\
Italy & 240 & 260 & $+8 \%$ \\
Spain & 110 & 140 & $+27 \%$ \\
Belgium & 35 & 46 & $+30 \%$ \\
Finland & 10 & 15 & $+50 \%$ \\
Ireland & 32 & 15 & $-53 \%$ \\
Greece & 61 & 50 & $-18 \%$ \\
\hline
\end{tabular}

Source: Monte dei Paschi di Siena; Sg Cib Global Capital Markets

Table 3: average debt/GDP levels of EMU countries pre and post-EMU

\begin{tabular}{cccc}
\hline & $\mathbf{1 9 7 0 - 2 0 0 8}$ & $\mathbf{1 9 7 0 - 1 9 9 6}$ & $\mathbf{1 9 9 7 - 2 0 0 8}$ \\
\hline Austria & 48.84 & 41.88 & 64.5 \\
Belgium & 97.28 & 95.43 & 101.44 \\
Finland & 26.99 & 20.00 & 42.72 \\
France & 40.26 & 30.74 & 61.68 \\
Germany & 42.10 & 32.83 & 62.96 \\
Greece & 63.16 & 46.83 & 99.91 \\
Ireland & 65.75 & 78.25 & 37.62 \\
Italy & 85.90 & 75.92 & 108.35 \\
Netherlands & 58.07 & 59.53 & 54.78 \\
Portugal & 48.55 & 44.00 & 57.65 \\
Spain & 37.36 & 31.36 & 50.87 \\
MEDIAN & 48.84 & 44.00 & 61.68 \\
MEAN & 55.84 & 50.62 & 67.50 \\
\hline
\end{tabular}

Source: OECD Economic Outlook 85, authors’ calculations. 
Table 4. Responses to a 1\% government debt (debt) shock (all countries; 1970-2008)

\begin{tabular}{cccc}
\hline Response of $\rightarrow$ & debt & GDP & Int. rate \\
& & & \\
\hline 0 & $1.00^{* * *}$ & $-0.07^{* * *}$ & 0.06 \\
1 & $0.55^{* * *}$ & 0.00 & 0.09 \\
2 & $0.29^{* * *}$ & 0.02 & 0.10 \\
3 & $0.15^{* * *}$ & 0.02 & 0.09 \\
4 & $0.08^{*}$ & 0.01 & 0.06 \\
5 & 0.04 & 0.01 & $0.04 *$ \\
6 & 0.02 & 0.00 & 0.02 \\
\hline
\end{tabular}

***, **, *: significant at 1,5 and $10 \%$

Table 5. Responses to a 1\% government debt (debt) shock (all countries; 1970-1996)

\begin{tabular}{cccc}
\hline Response of $\rightarrow$ & debt & GDP & Int. rate \\
\hline 0 & $1.00^{* * *}$ & $-0.06^{* * *}$ & $0.20^{* *}$ \\
1 & $0.56^{* * *}$ & 0.00 & $0.17^{*}$ \\
2 & $0.31^{* * *}$ & 0.01 & $0.19^{* *}$ \\
3 & $0.18^{* * *}$ & 0.01 & $0.16^{* *}$ \\
4 & $0.11^{* * *}$ & 0.00 & $0.10^{* *}$ \\
5 & $0.07^{* *}$ & 0.00 & $0.06^{* *}$ \\
6 & $0.04^{* *}$ & 0.00 & $0.03^{*}$ \\
\hline ***, **, *: significant at 1,5 and $10 \%$ &
\end{tabular}

Table 6. Responses to a 1\% government debt (debt) shock (high debt countries; 1970-1996)

\begin{tabular}{cccc}
\hline Response of $\rightarrow$ & debt & GDP & Int. rate \\
\hline 0 & $1.00^{* * *}$ & -0.03 & $0.43^{* *}$ \\
1 & $0.53^{* * *}$ & -0.02 & $0.42^{* * *}$ \\
2 & $0.28^{* *}$ & -0.01 & $0.25^{* *}$ \\
3 & 0.15 & -0.01 & 0.12 \\
4 & 0.08 & -0.00 & 0.06 \\
5 & 0.04 & -0.00 & 0.03 \\
6 & 0.02 & -0.00 & 0.01 \\
\hline *** ** *. significant at 1,5 and $10 \%$ &
\end{tabular}

$* * *, * *, *$ : significant at 1,5 and $10 \%$ 
Table 7. Responses to a $1 \%$ government debt (debt) shock (low debt countries; 1970-1996)

\begin{tabular}{cccc}
\hline Response of $\rightarrow$ & debt & GDP & Int. rate \\
& & & \\
\hline 0 & $1.00^{* * *}$ & $-0.07^{* * *}$ & $0.15^{*}$ \\
1 & $0.59^{* * *}$ & 0.00 & 0.10 \\
2 & $0.31^{* * *}$ & $0.03^{*}$ & 0.16 \\
3 & $0.16^{* *}$ & $0.03^{* *}$ & $0.17^{* *}$ \\
4 & 0.08 & $0.02^{*}$ & $0.14^{* *}$ \\
5 & 0.05 & 0.01 & $0.10^{* *}$ \\
6 & 0.03 & 0.00 & $0.06^{*}$ \\
\hline
\end{tabular}

***, $* *, *$ : significant at 1,5 and $10 \%$

Table 8. Responses to a 1\% government debt (debt) shock (high debt countries; 1970-2008)

\begin{tabular}{|c|c|c|c|}
\hline Response of $\rightarrow$ & $\overline{d e b t}$ & GDP & Int. rate \\
\hline 0 & $1.00^{* * *}$ & $-0.05^{* *}$ & 0.08 \\
\hline 1 & $0.48^{* * *}$ & -0.01 & 0.20 \\
\hline 2 & $0.24 * *$ & -0.01 & 0.15 \\
\hline 3 & $0.12^{*}$ & -0.01 & 0.09 \\
\hline 4 & 0.06 & -0.01 & 0.04 \\
\hline 5 & 0.03 & -0.00 & 0.02 \\
\hline 6 & 0.02 & -0.00 & 0.01 \\
\hline
\end{tabular}

***, **, *: significant at 1,5 and $10 \%$

Table 9. Responses to a 1\% government debt (debt) shock (low debt countries; 1970-2008)

\begin{tabular}{cccc}
\hline Response of $\rightarrow$ & debt & GDP & Int. rate \\
& & & \\
\hline 0 & $1.00^{* * *}$ & $-0.07^{* * *}$ & 0.07 \\
1 & $0.58^{* * *}$ & 0.01 & 0.05 \\
2 & $0.31^{* * *}$ & 0.03 & 0.09 \\
3 & $0.16^{* *}$ & $0.03^{*}$ & 0.10 \\
4 & 0.07 & $0.03^{* *}$ & 0.09 \\
5 & 0.03 & 0.02 & 0.07 \\
6 & 0.01 & 0.01 & 0.04 \\
\hline
\end{tabular}

***, **, *: significant at 1, 5 and $10 \%$ 


\section{Figures}

Figure 1. Responses to a 1\% government debt shock (all countries; 1970-2008)
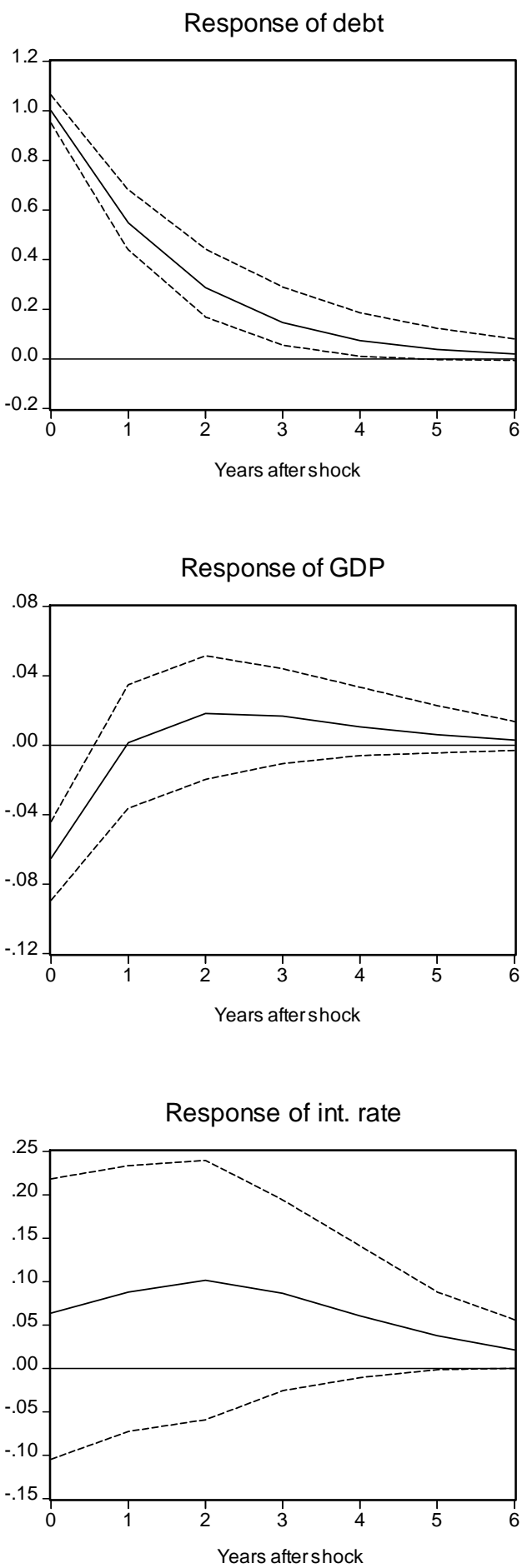

Note: Confidence bands are the 5th and 95th percentiles from Monte Carlo simulations based on 200 replications. 
Figure 2. Responses to a 1\% government debt shock (three different subsamples; 1970-1996)
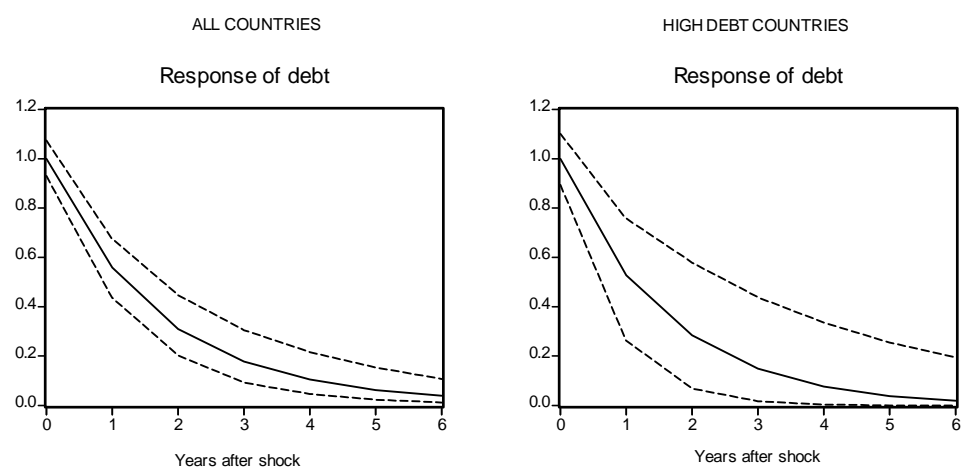

LOW DEBT COUNTRIES
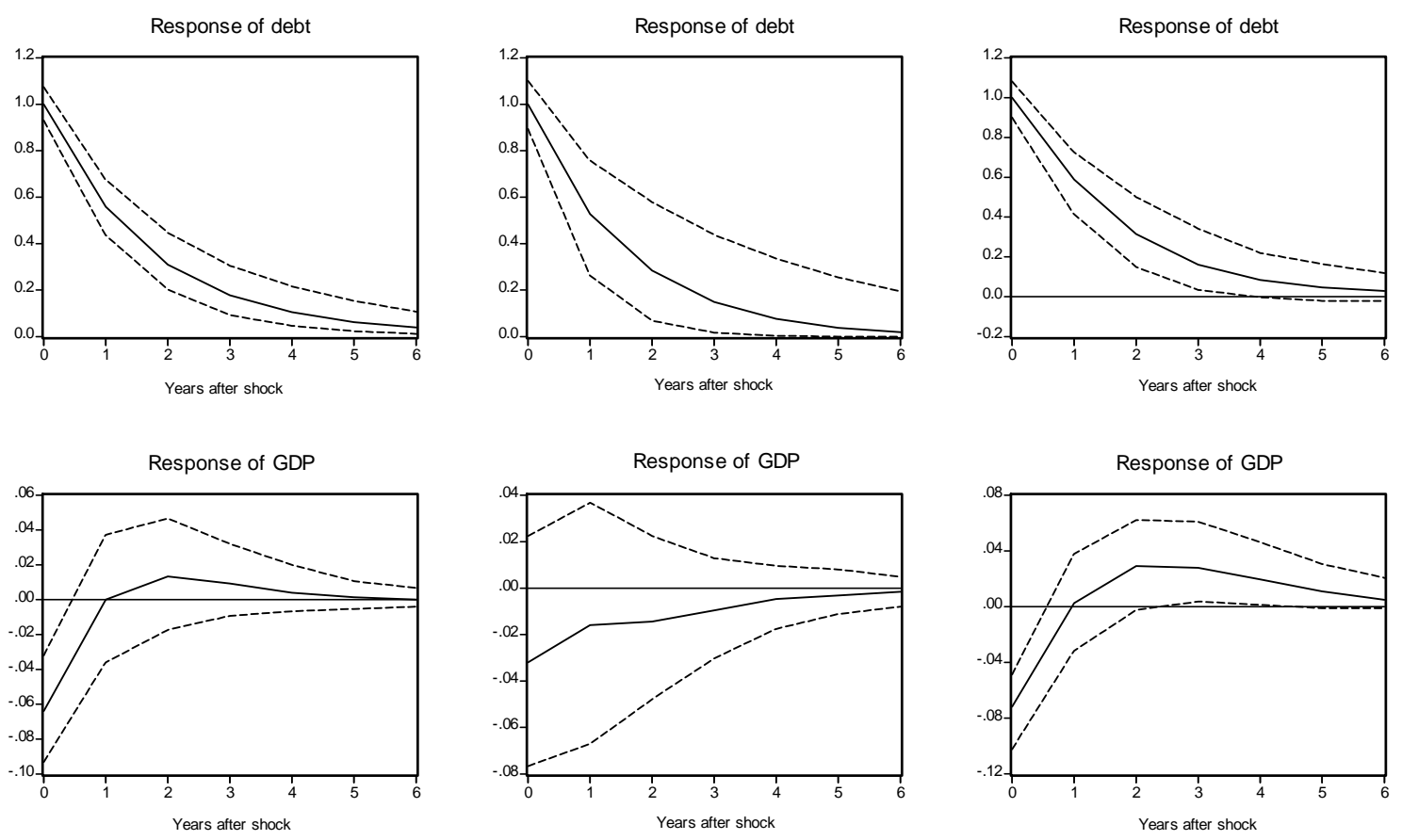

sponse of int. rate
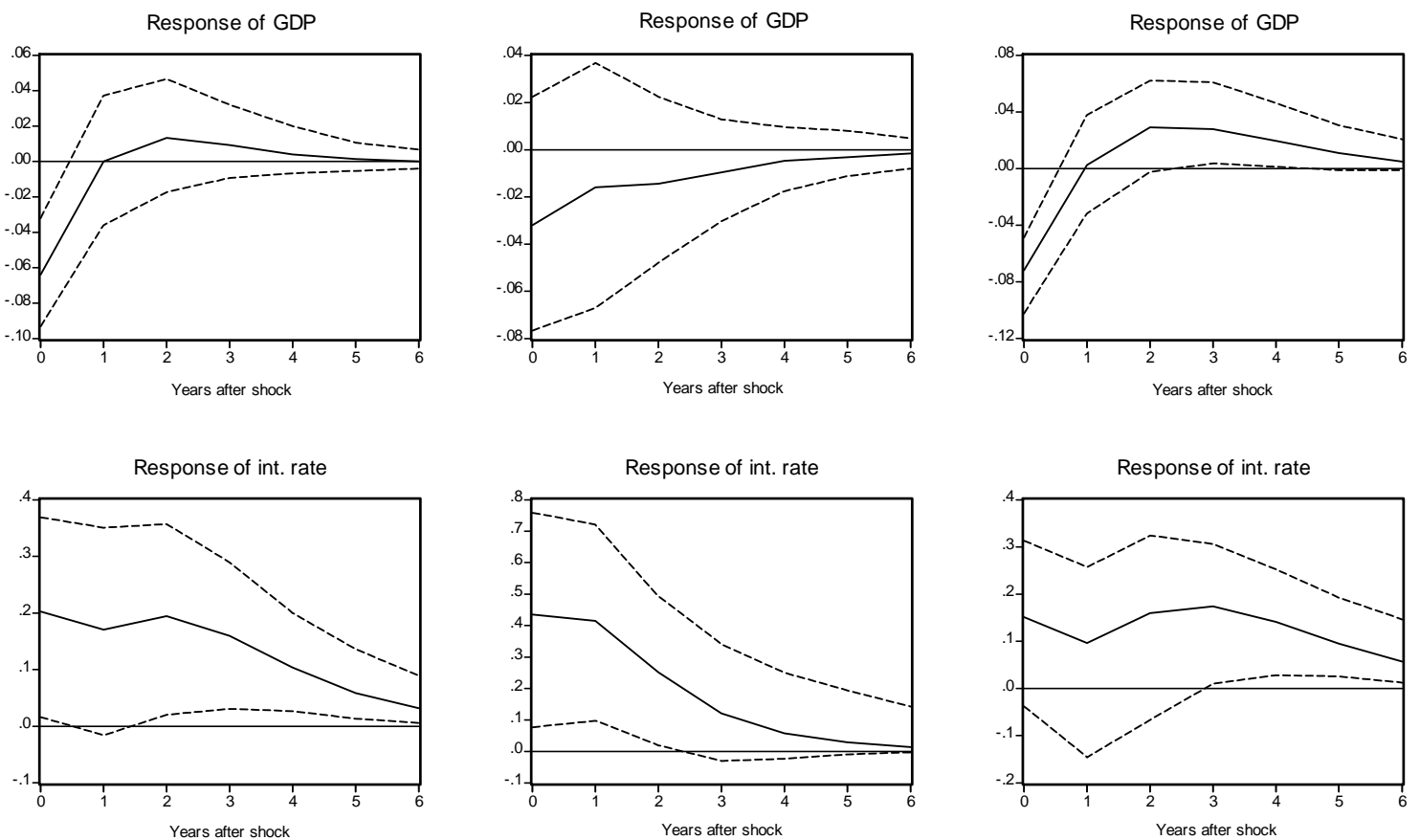

Note: Confidence bands are the 5th and 95th percentiles from Monte Carlo simulations based on 200 replications. 
Figure 3. Responses to a 1\% government debt shock (two different subsamples; 1970-2008)

HIGH DEBT COUNTRIES

Response of debt

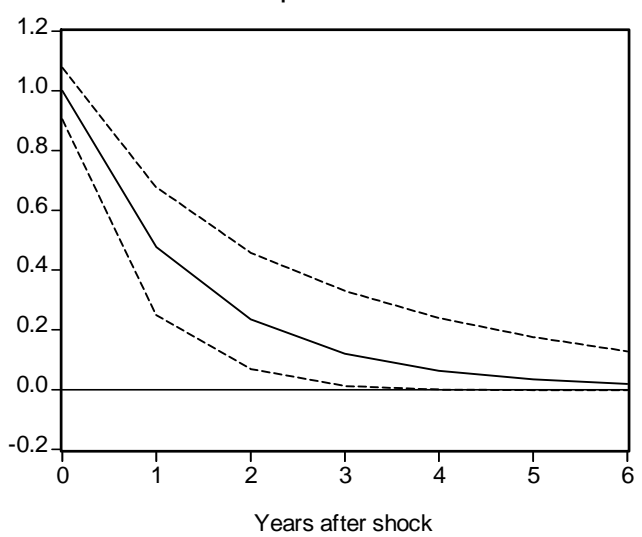

Response of GDP

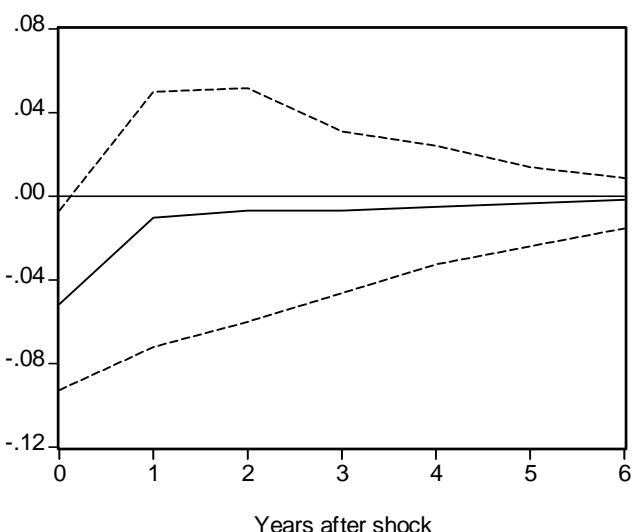

Response of int. rate

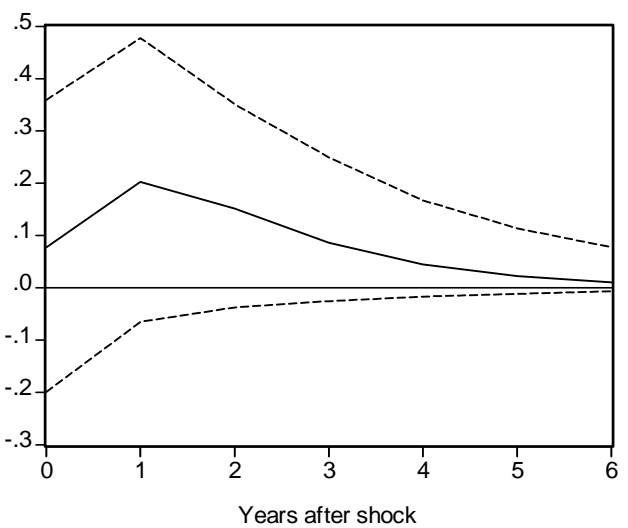

LOW DEBT COUNTRIES

Response of debt

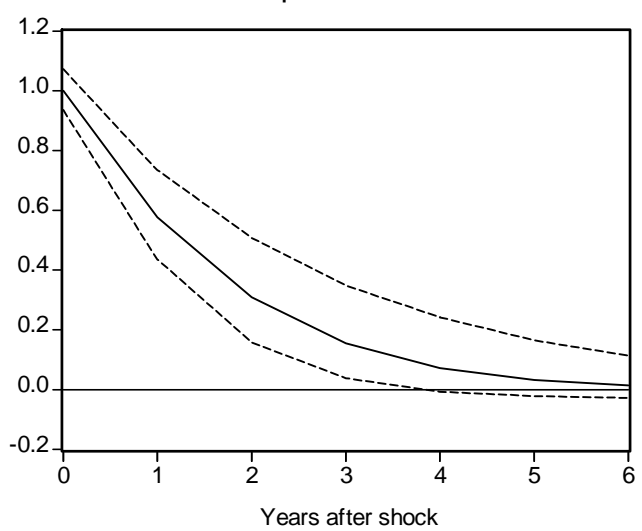

Response of GDP

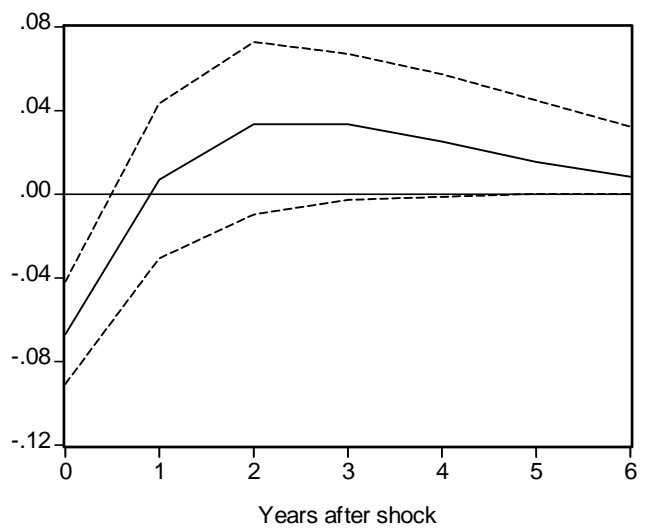

Response of int. rate

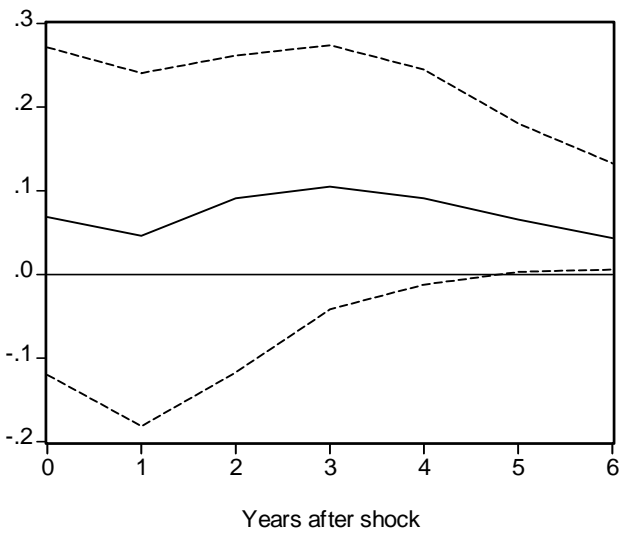

Note: Confidence bands are the 5th and 95th percentiles from Monte Carlo simulations based on 200 replications. 
Figure 4: Robustness check (sample variation), responses to a 1\% government debt shock

1970-2008

Response of debt

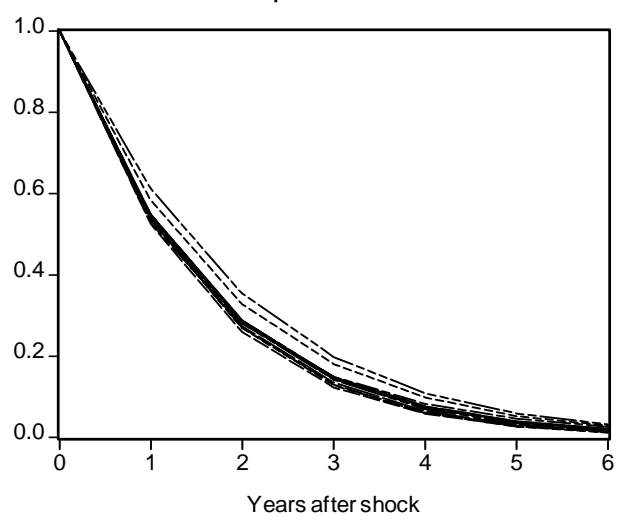

Response of GDP

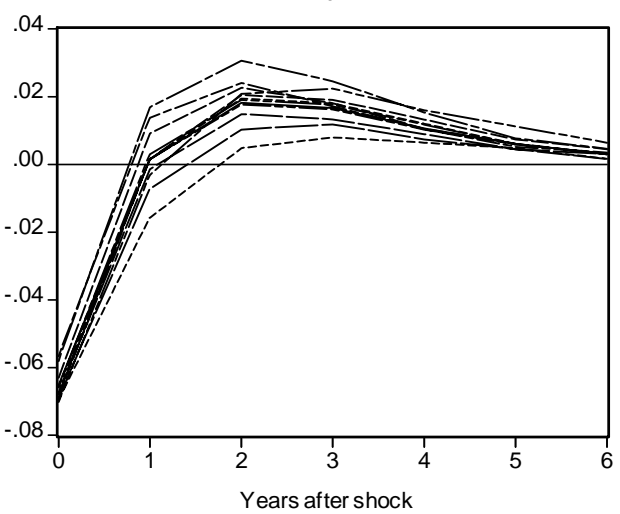

Response of int. rate

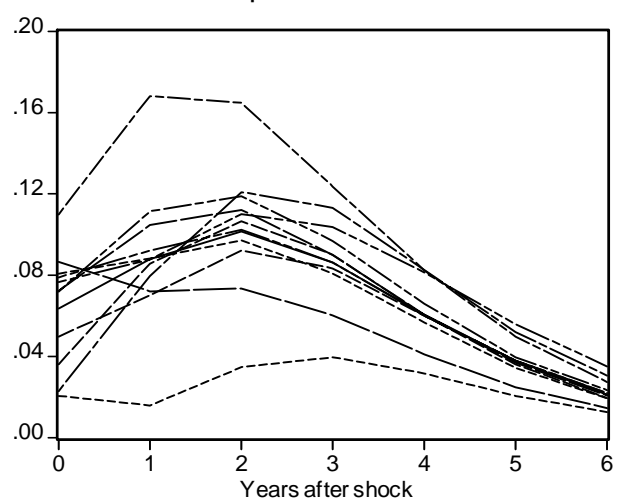

1970-1996

Response of debt

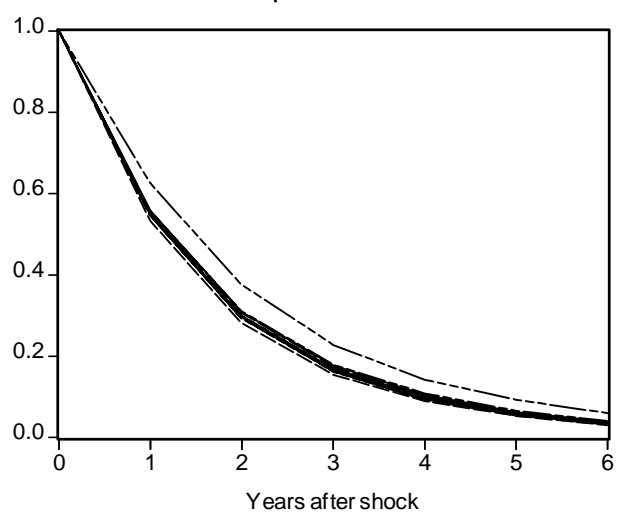

Response of GDP

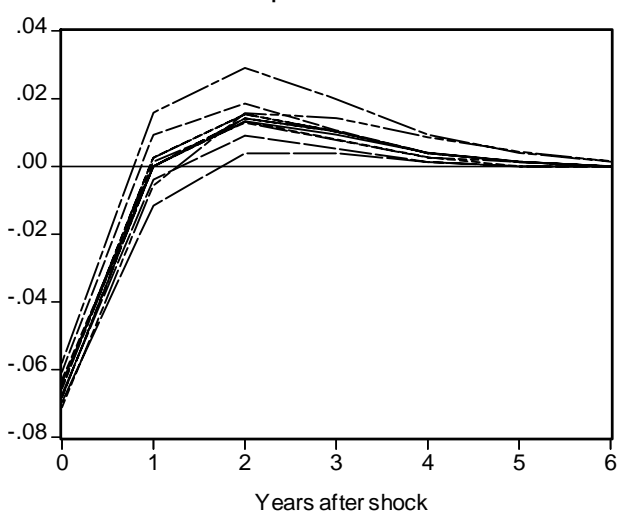

Response of int. rate

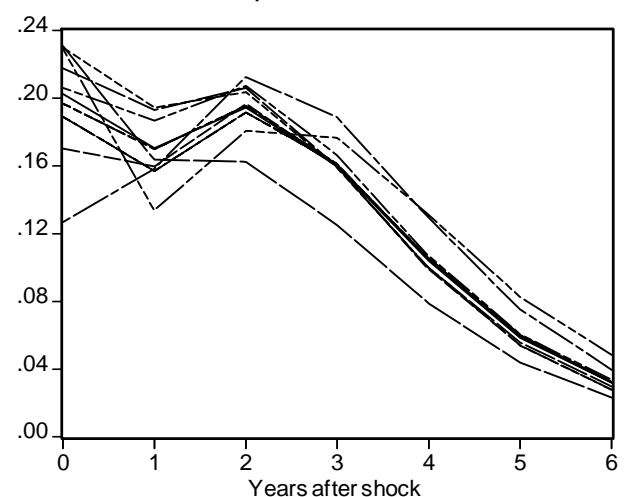

\begin{tabular}{|lll|}
\hline All countries & --- No France & -- No Italy \\
---- No Austria & - No Germany & - No Netherlands \\
--- No Belgium & --- No Greece & ---- No Portugal \\
--- No Finland & -- No Ireland & --- No Spain
\end{tabular}

Note: solid lines are the baseline VAR estimates; dotted lines are the point estimates of the impulse responses coming from the eleven different VARs obtained by excluding one country of the sample at a time. 